\title{
Zasoby rzadkie w planach strategicznych peryferyjnych gmin wiejskich
}

\section{Rare resources in the strategic plans of peripheral rural communes}

\section{Jacek SOŁTYS}

Uniwersytet Warmińsko-Mazurski w Olsztynie Wydział Geodezji, Inżynierii Przestrzennej i Budownictwa, Katedra Planowania i Inżynierii Przestrzennej ul. Prawocheńskiego 15, 10-720 Olsztyn jacek.soltys@uwm.edu.pl, jacek.soltys@gmail.com

Zarys treści: Celem artykułu jest rozpoznanie roli rzadkich, specyficznych (w tym unikatowych) zasobów w strategiach rozwoju wybranych gmin wiejskich peryferyjnych (czyli położonych poza podregionami dużych miast). Gminy do badań dobierano spośród gmin: o najwyższych dochodach własnych na 1 mieszkańca średnio w latach 2010-2014, o najwyższym wskaźniku osób fizycznych prowadzących działalność gospodarczą na 1000 osób w wieku produkcyjnym, a także posiadających rzadkie zasoby (uzdrowisko, atrakcje krajoznawcze). Gminy sąsiadujące z miastem były wyłączone z badań. Źródłem informacji były listy czynników sytuacyjnych do analizy SWOT i inne elementy treści zawarte $w$ badanych strategiach. Jako metody badawcze stosowane były: analiza i klasyfikacja badanych zasobów oraz analiza innych części badanych dokumentów. Stwierdzono, że najbardziej do rozwoju gmin wiejskich przyczyniły się surowce mineralne (węgiel brunatny) i walory turystyczne, zwłaszcza morze z plażami. Dokumenty strategiczne gmin mają zróżnicowaną jakość. W wielu z nich w niedostatecznym stopniu eksponuje się specyfikę zasobów. Powszechne są błędy metodyczne w analizie SWOT. Rzadko spotyka się dobrą misję.

Słowa kluczowe: analiza strategiczna SWOT, gminy wiejskie peryferyjne, strategie rozwoju, zasoby rzadkie, zasoby specyficzne.

\section{Wstęp}

Zasoby wewnętrzne, zwłaszcza rzadkie (tym bardziej specyficzne, unikatowe), stanowią istotny czynnik uzyskiwania przewagi konkurencyjnej przyczyniającej się do rozwoju. Ich wykorzystywanie należy do istoty idei lokalności i rozwoju zwanego endogenicznym (Chądzyński i in. 2007; Grosse 2007; Hausner 2008), czasem też oddolnym, partycypacyjnym, społecznym (Ray 2001).

Rozpoznanie zasobów i planowanie sposobu ich wykorzystania w polityce wspomagania rozwoju prowadzonej przez gminy jest zadaniem planowania strategicznego. Planowanie to, rozwinięte w podmiotach gospodarczych, zostało przeniesione do innych typów podmiotów, w tym jednostek terytorialnych, mimo wielu różnic między taką jednostką a podmiotem gospodarczym. Jest też i wiele podobieństw, które skłaniają do stosowania 
planowania strategicznego i wielu jego metod w jednostkach samorządowych, różnice natomiast są źródłem problemów metodycznych i niektórych błędów.

Korzystając ze słownikowej definicji słowa specyficzny (Inny słownik... 2000), można przyjąć, że specyficzny zasób danego terytorium to taki, którego cechy są tylko dla niego charakterystyczne. Są jednak takie zasoby, które występują na kilku lub większej liczbie terytoriów, ale nie powszechnie, a różnice między nimi są na tyle nieistotne, że nie spełniają definicji specyficzności. Takie zasoby oraz zasoby specyficzne objęto w tym artykule ogólną nazwę zasoby rzadkie.

Przedmiotem zainteresowania autora są rzadkie zasoby wewnętrzne jako wyłączne lub główne czynniki rozwoju obszarów wiejskich. Aby wyeliminować z badań gminy rozwijające się pod wpływem miasta, z pewnym naddatkiem wyłączono w procedurze wyboru w pierwszej kolejności całe podregiony NTS3 miast wojewódzkich, innych dużych miast (Bielska-Białej, Częstochowy, Radomia) i aglomeracji miejskich górniczo-przemysłowych (podregion rybnicki i legnicko-głogowski). Pozostały obszar i gminy na ich obszarze nazwano peryferyjnymi (rys. 1). Z tego obszaru wyłączono gminy miejsko-wiejskie, a z pozostałych 1019 peryferyjnych gmin wiejskich wybrano do badań 21 w sposób opisany w dalszej części artykułu.

Celem prezentowanych badań jest rozpoznanie roli rzadkich zasobów w strategiach rozwoju ${ }^{1}$ badanych gmin. Cel ten realizowano poprzez poszukiwanie odpowiedzi na następujące pytania:

- Jakie zasoby wymieniono na listach czynników rozwojowych w dokumentach strategicznych? Jak można je usystematyzować?

- Które z tych zasobów są podstawą rozwoju planowanego w strategiach?

Źródłami informacji były strategie rozwoju (lub ich odpowiedniki) 21 badanych gmin, (zwłaszcza listy mocnych stron do analizy SWOT, wizje, misje, cele i sposoby ich osiągania), a także Bank Danych Lokalnych (BDL) GUS i rozmowy z pracownikami gmin.

Jako metody badawcze zastosowano analizę i systematykę (klasyfikację) badanych czynników oraz analizę innych części badanych dokumentów, w tym: misji, struktury celów i działań wraz z oceną stopnia nawiązywania do rozpoznanych zasobów.

Analizując dokumenty strategiczne, nie sposób nie zauważyć ich wad oraz zróżnicowania sposobu podania treści - utrudniających prowadzenie analiz. Dlatego ubocznym efektem badań było wzbogacenie wiedzy dotyczącej planowania strategicznego, w tym stosowanych metod i najczęściej popełnianych błędów. I metody, i błędy są powszechnie znane, ale wyniki badań poszerzają ich udokumentowanie. W tym zakresie jest to kontynuacja dotychczasowych badań autora dotyczących planowania strategicznego i jego metod (Sołtys 2008) oraz badań czynników rozwoju i wykorzystania tych czynników (Sołtys 2014).

Drugim ubocznym efektem badań było sprawdzenie, jakie zasoby faktycznie wpływały na uzyskiwanie przez gminy najwyższych wskaźników rozwoju.

\footnotetext{
1 Nazwa ta jest zdaniem autora nieprawidłowa, choć zawarta w Ustawie [z 6 grudnia 2006] i tytułach badanych dokumentów - dlatego tu używana. Strategia jest planem działania - w dopełniaczu powinien być rzeczownik odczasownikowy, np. strategia pobudzania, wspomagania, równoważenia rozwoju gminy, strategia zarządzania rozwojem gminy.
} 


\section{Wybór gmin do badań, ich cechy i cechy ich strategii}

Założono dwukierunkowe poszukiwanie/dobór gmin do badań:

- kierunek główny - spośród jednostek o wysokim poziomie rozwoju; poszukiwano następnie zasobów, które przyczyniły się do ich rozwoju;

- kierunek uzupełniający - spośród gmin o wybitnych, znanych zasobach, bez względu na poziom rozwoju.

W ramach głównego kierunku poszukiwań jako peryferyjne gminy wiejskie o wysokim poziomie rozwoju uwzględniono jednostki:

- o najwyższych średnich dochodach własnych budżetu gminy na 1 mieszkańca w latach 2010-2014;

- o najwyższych wartościach wskaźnika przedsiębiorczości, czyli liczby osób fizycznych prowadzących działalność gospodarczą na 1000 osób w wieku produkcyjnym.

Średnie dochody własne budżetu per capita w latach 2010-2014 przekraczały 1,8-krotnie i więcej średnią krajową peryferyjnych gmin wiejskich w 35 jednostkach. Aż 17 z nich sąsiaduje z miastami, więc gminy te wyłączono z dalszych badań, uznając, że miasto mogło mieć istotny wpływ na ich rozwój. Wśród pozostałych 18 jest 6 gmin górniczych oraz 6 turystycznych: 3 nadmorskie i 3 górskie. Nie wszystkie z nich mają strategie. Jej brak w gminie Sulmierzyce może zastąpić Plan Rozwoju Lokalnego (2009), a w gminie Narewka - Program Rozwoju Gminy Narewka na lata 2015-2020 (Szot-Gabryś 2015). Brak strategii lub jej odpowiedników dla trzech gmin wyłączyło je z dalszych badań. Zbadano zatem łącznie dokumenty 15 gmin (tab. 1) spośród wyżej wspomnianych 18 o wysokich dochodach własnych budżetu.

Uwzględniając gminy o najwyższej wartości wskaźnika przedsiębiorczości, włączono do zbioru gminę Włoszakowice, gdzie wartość ta wynosiła 18,2. Gminy o wyższych wartościach (niesąsiadujące z miastami) to: Rewal, Mielno, Lutowiska i Cisna - znajdujące się już wśród 15 uwzględnionych gmin o wysokich dochodach własnych budżetu (tab. 1).

W ramach uzupełniającego kierunku doboru poszukiwano innych gmin posiadających na swoim terytorium rzadkie, a zwłaszcza specyficzne zasoby: uzdrowiska, skanseny, parki narodowe lub inną wybitną atrakcję krajoznawczą. Są tylko dwie gminy wiejskie z uzdrowiskami niesąsiadujące z miastem: Uście Gorlickie i Horyniec Zdrój. Obie uwzględniono. Spośród nielicznych gmin wiejskich posiadających skansen i niesąsiadujących z miastem wybrano Smołdzino, na terenie której jest również część parku narodowego oraz Jabłonkę (gminę górską przygraniczną). Jako gminę posiadającą inną wybitną atrakcję krajoznawczą wybrano Grunwald. Listę 21 gmin, których dokumenty strategiczne zbadano, zawiera tabela 1. Ich położenie ukazuje rycina 1. 
Tabela 1. Wybrane cechy badanych gmin i ich strategii

\begin{tabular}{|c|c|c|c|c|c|c|c|}
\hline \multirow[b]{2}{*}{$\begin{array}{l}\text { Typ } \\
\text { gminy }\end{array}$} & \multirow[b]{2}{*}{ Symbol $^{a}$} & \multirow[b]{2}{*}{ Gmina } & \multirow[b]{2}{*}{ 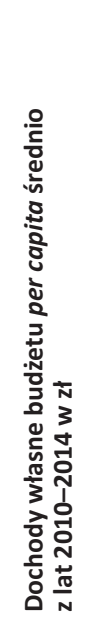 } & \multirow[b]{2}{*}{ 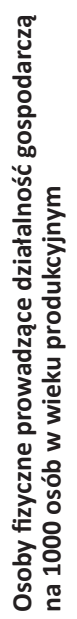 } & \multirow[b]{2}{*}{ 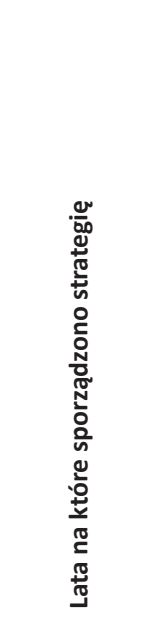 } & \multicolumn{2}{|c|}{$\begin{array}{c}\text { Cechy list czynników } \\
\text { do SWOT }\end{array}$} \\
\hline & & & & & & 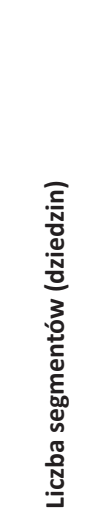 & 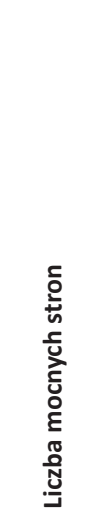 \\
\hline tn & $\operatorname{Re}$ & Rewal & 10654 & 46,6 & 2012-2020 & 3 & $51^{b}$ \\
\hline tn & Mo & Mielno & 4941 & 36,2 & 2014-2022 & 1 & $4 / 6 / 13^{c}$ \\
\hline tn & Ps & Postomino & 2428 & 10,5 & 2007-2015 & 1 & 32 \\
\hline tn & Sm & Smołdzino & 1076 & 8,7 & $2016-2-26$ & 1 & 14 \\
\hline $\operatorname{tg}$ & So & Solina & 3328 & 17,2 & 2015-2025 & 3 & 35 \\
\hline $\operatorname{tg}$ & C & Cisna & 2984 & 18,8 & 2008-2020 & 9 & 59 \\
\hline $\operatorname{tg}$ & L & Lutowiska & 2369 & 20,1 & 1997-2010 & $3 / 16^{c}$ & 122 \\
\hline $\operatorname{tg}$ & $U$ & Uście Gorlickie & 1174 & 11,2 & $x$ & 1 & 8 \\
\hline $\operatorname{tg}$ & J & Jabłonka & 909 & 6,9 & 2015-2020 & 1 & 15 \\
\hline $\mathrm{p}$ & Mk & Mielnik & 5002 & 5,6 & 2001-2010 & 1 & 12 \\
\hline $\mathrm{p}$ & Pw & Powidz & 4006 & 10,2 & $x$ & 7 & 30 \\
\hline$p$ & $\mathrm{~N}$ & Narewka & 2523 & 5,6 & 2015-2020 & 6 & 69 \\
\hline$p$ & $\mathrm{Rz}$ & Rzeczenica & 2397 & 7,3 & 2007-2020 & 1 & 9 \\
\hline $\mathrm{p}$ & $\mathrm{Bu}$ & Buczek & 2100 & 9,3 & 2015-2020 & 1 & 14 \\
\hline$p$ & $\mathrm{H}$ & Horyniec & 1316 & 5,9 & 2015-2020 & 1 & 25 \\
\hline$p$ & W & Włoszczakowice & 1200 & 18,2 & 2004-2013 & 5 & 45 \\
\hline$p$ & G & Grunwald & 1097 & 5,4 & 2016-2026 & 1 & 11 \\
\hline g & $\mathrm{KI}$ & Kleszczów & 46454 & 6,3 & 2015-2030+ & 1 & 32 \\
\hline g & $\mathrm{Sz}$ & Szczerców & 3738 & 8,8 & 2016-2022 & 1 & 14 \\
\hline $\mathrm{g}$ & Su & Sulmierzyce & 2494 & 6,1 & 2009-2015 & 3 & 19 \\
\hline $\mathrm{g}$ & $\mathrm{Br}$ & Brudzew & 2239 & 6,1 & 2003-2013 & 1 & 22 \\
\hline
\end{tabular}

${ }^{a}$ używany w tab. 2 i 3, ${ }^{b}$ w tym 4 zewnętrzne, ${ }^{c}$ bardziej i mniej ogólne, $x$ - brak informacji tn - turystyczne nadmorskie, $\mathrm{tg}$ - turystyczne górskie, g - górnicze, $\mathrm{p}$ - pozostałe Źródło: BDL GUS (stat.gov.pl) i dokumenty strategiczne według spisu literatury. 


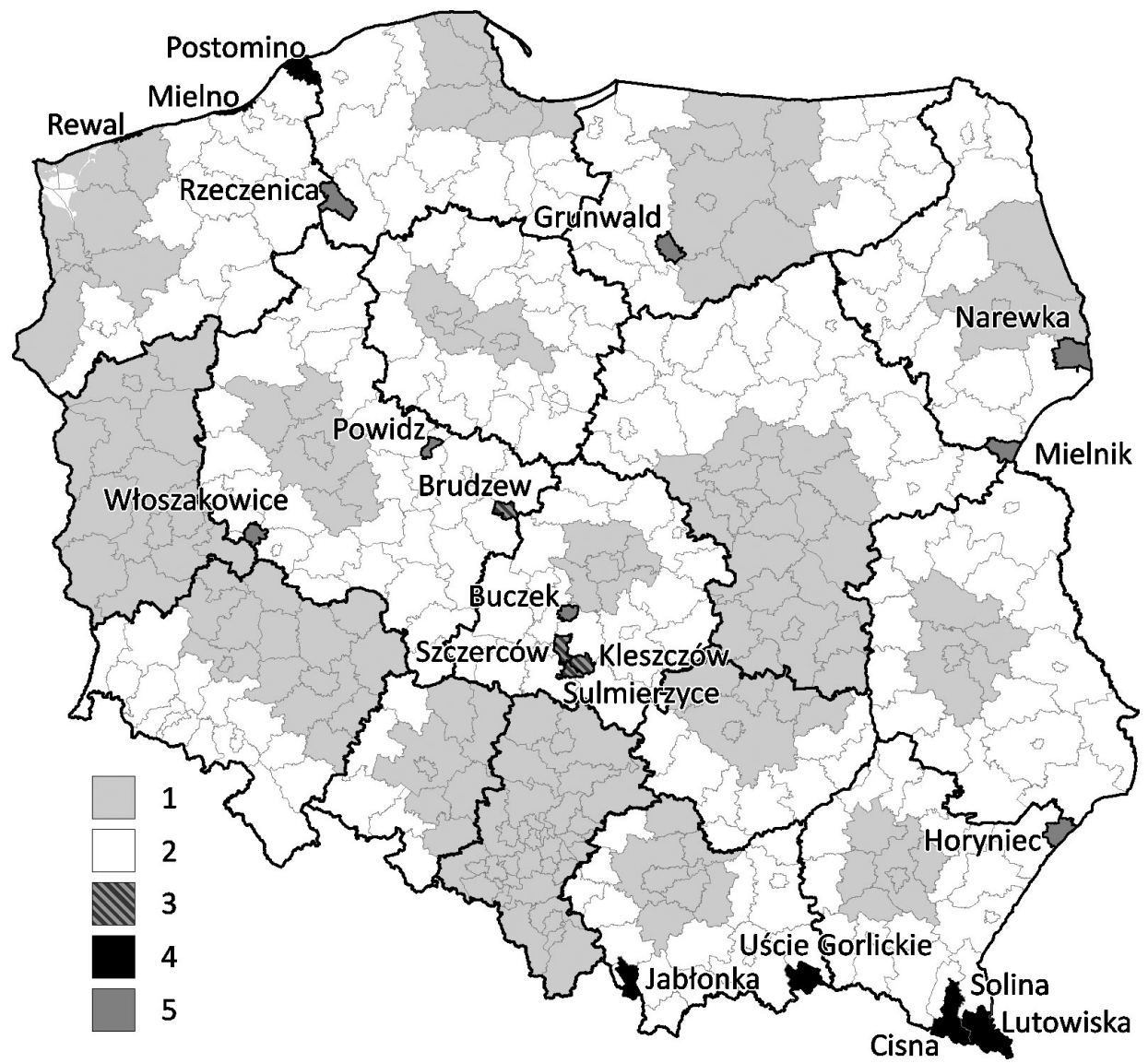

Ryc. 1. Badane gminy na tle obszarów peryferyjnych Polski

1 - podregiony NTS3 miast wojewódzkich, innych dużych miast i aglomeracji miejskich górniczo-przemysłowych - wyłączone z analiz; 2 - obszary peryferyjne; badane gminy: 3 - górnicze, 4 - turystyczne, 5 - pozostałe. Examined communes on the background of peripheral areas of Poland

1 - NTS3 sub-regions of voivodeship capital cities, other big cities and urban mining-industrial agglomerations - excluded from analysis; 2 - peripheral areas; examined communes: 3 - mining, 4 - tourist, 5 - other.

\section{Zasoby jako czynniki rozwojowe i sposób ich przedstawienia w dokumentach strategicznych}

Źródłem informacji o zasobach były listy czynników rozwojowych, zwanych też sytuacyjnymi, sporządzone w ramach analizy strategicznej SWOT. Różna forma i jakość tych list utrudniała ich analizę. I tak, w 8 gminach listy czynników były tworzone w obrębie poszczególnych segmentów (sfer, dziedzin - tab. 1). Wpłynęło to na nadmierną liczbę czynników i małą istotność niektórych z nich. Jednak i przy braku podziału na segmenty czynników jest czasem zbyt wiele, są zbyt szczegółowe i wykraczające poza poziom strategiczny i poza problematykę rozwoju, np.: domy strażaka, oświetlenie dróg i ulic.

Wadą jest niedostatek relatywizacji czynników, czyli rozpoznawania ich poprzez odniesienia do gmin konkurencyjnych. Jako silne strony wymieniane są zasoby i zjawiska wystę- 
pujące w wielu gminach, np. sprawnie działająca administracja gminy, selektywna zbiórka odpadów, a nawet w każdej gminie: funkcjonująca biblioteka gminna, obiekty sakralne. W niektórych gminach takie było nawet założenie - wskazywania wszelkich pozytywów. Tymczasem za silne strony należy uważać te zasoby i umiejętności, w których dana organizacja (tu: gmina) ma przewagę nad konkurentami (Pierścionek 2003). Wadą szczególnie istotną z punktu widzenia poszukiwania specyfiki zasobów jest zbytnia ogólność sformułowań dotycząca niektórych czynników, np. zasoby naturalne, drogi, oświata (Strategia Rozwoju Społeczno-Gospodarczego Gminy Postomino... 2007). Obie wyżej wymienione wady utrudniają ocenę, czy dany zasób wymieniony jako mocna strona faktycznie nią jest w porównaniu z innymi gminami. Np. takie zasoby instytucjonalne i społeczne, jak: OSP i ich liderzy, aktywna społeczność lokalna - mogą stanowić mocną stronę i być może w niektórych gminach stanowią, jednak bez specjalnych badań trudno jest to potwierdzić. Pochodną powyższych wad jest niedostatek eksponowania specyfiki czynników.

W analizowanych dokumentach zróżnicowany jest sposób redagowania czynników z punktu widzenia ogólności i konkretności sformułowań oraz stopnia rozdrobnienia list. W niektórych gminach kilka czynników tego samego rodzaju zapisano jako jeden, z konkretyzacją w nawiasach lub po dwukropku, np.:

- w gminie Powidz: walory przyrodniczo-krajobrazowe, głównie: czyste jeziora, lasy, ciekawy krajobraz, wiele unikalnych okazów flory i fauny (Strategia zrównoważonego rozwoju... 2002);

- w gminie Narewka: „bogactwo przyrodnicze: Puszcza Białowieska, nieskażone środowisko, zbiornik wodny Siemianówka, sieć rzeczna” oraz „tradycje kulturowe: zespoły ludowe i folklor, rękodzieło ludowe, bogaty kalendarz wydarzeń kulturalnych (imprezy, plenery malarskie, wystawy)" (Szot-Gabryś 2015, s. 39).

Niekiedy w treściach można dopatrzeć się poziomów hierarchicznych, np.:

„Walory przyrodnicze, na które składają się:

- nadmorskie położenie, w tym wysokiej jakości szerokie plaże, mikroklimat nadmorski, kąpieliska nadmorskie,

- formy przyrody i atrakcje przyrodnicze wynikające z położenia nad jeziorem Jamno, w tym mierzeja i Kanał Jamneński" (Strategia Rozwoju Gminy Mielno... 2014, s. 68, podział na punkty dokonany przez autora).

Powyższe formy zapisu nie są wadą, ale ich zróżnicowanie i hierarchia treści (jak w ostatnim przykładzie) utrudniają analizę list czynników i ich klasyfikację oraz utrudniają, a nawet uniemożliwiają analizę statystyczną (ostatni przykład stanowi na liście jeden czynnik, ale można też doliczyć się ich dwóch, trzech, a nawet pięciu).

Ewidentną wadą listy czynników są powtórzenia treści merytorycznie podobnych, lecz inaczej nazwanych lub zawierających się jedne w drugich, jak np. w strategii gminy Rzeczenica: „znaczne obszary o czystym środowisku naturalnym, gmina czysta ekologicznie” (Strategia Rozwoju Gminy Rzeczenica... 2007, s. 44). Prawdopodobną przyczyną tego jest praca w grupach, a następnie nieuważna redakcja dokumentu.

W dalszej fazie badań uwzględniono jedynie czynniki uznane za faktyczne i pewne mocne strony, będące zasobami. Zasoby sklasyfikowano m.in. według jednego z kryteriów stosowanych w nawiązaniu do dorobku szkoły bliskości, jakim jest powszechność albo rzadkość wstępowania (Zajda 2013). Wyodrębniono trzy klasy zasobów rzadkich niewykazujących istotnej specyfiki oraz dodatkowo rozróżniono specyfikę i unikatowość, rozpatrując wszystkie te kategorie w skali Polski. Za unikatowe, zgodnie z dosłownym znaczeniem 
tego słowa, uznano zasoby jedyne w swoim rodzaju, występujące jako jeden obiekt, w jednym miejscu w Polsce, a także jako odrębny typ lub osiągające najwyższy poziom (np. rozmiar). Należy jednak zauważyć, że unikatowość ma charakter względny. Unikatowych (niepowtarzalnych) jest wiele wartości kulturowych. Każdy krajobraz (jako fizjonomia) jest unikatowy. Jednak między wieloma z nich istnieją podobieństwa, co jest podstawą hierarchicznych typologii. Takie zasoby, powtarzalne co do rodzaju, ale w których wykorzystaniu (np. w turystyce krajoznawczej) istotny jest ich indywidualny, niepowtarzalny charakter, sklasyfikowano jako specyficzne, a w kilku przypadkach (Puszcza Białowieska, pola bitwy pod Grunwaldem) jako unikatowe, przy czym to rozróżnienie ma charakter subiektywny i arbitralny. Za specyficzne uznano obszary objęte ochroną przyrody, chociaż nie wynika to ze sformułowań, lecz z ich charakteru. Klasyfikacja zasobów zawartych na listach mocnych stron zawiera zatem następujące typy: (podane symbole użyto w tabeli 2 i 3):

- U1 - unikatowe jako jedyne w swoim rodzaju,

- U2 - unikatowe jako osiągające najwyższy poziom w Polsce,

- S-specyficzne (objaśnione powyżej),

- R1, R2, R3 - rzadkie, niewykazujące istotnej specyfiki o zróżnicowanym poziome rzadkości: R1 - najrzadsze, występujące w kilku gminach, R2 - występujące w kilkunastu gminach, R3 - występujące w kilkudziesięciu gminach,

- P - powszechne - występujące w większej liczbie gmin niż kilkadziesiąt.

Jako drugie kryterium klasyfikacji wprowadzono ich rodzaj (charakter), rozróżniając zasoby: przyrodnicze (p), kulturowe (k), społeczne (s), instytucjonalne (i), gospodarcze (g), techniczne i z zakresu zagospodarowania przestrzennego (z) oraz inne (x). Nawiązując do klasyfikacji potencjałów użytkowych (Przewoźniak 1991), zasoby przyrodnicze podzielono na: agroekologiczne (pa), leśne (pl), surowcowe (ps) i rekreacyjno-balneologiczne (pr).

Mocne strony - sklasyfikowane jako zasoby - ujęto: w tabeli 2 - indywidualne, niepowtarzalne w poszczególnych gminach i w tabeli 3 - zbiorczo zasoby występujące w więcej niż jednej gminie, używając sformułowań opisujących je najbardziej trafnie i zwięźle lub najczęściej występujące; w niektórych przypadkach zachowano oryginalne sformułowania różne w poszczególnych gminach, w niektórych odrębności wykazano w przypisach. Jeśli sformułowanie oryginalne ma charakter złożony i opisuje zasoby zaliczone do różnych klas, podano obie. Takie złożone zapisy ukazują czasem unikalne kombinacje zasobów, stanowiące wysoką wartość dla rozwoju. Nie jest to jednak właściwy sposób zapisu synergii zasobów. Zasoby powinny być ujmowane oddzielnie i badane ich związki.

Każda badana gmina zawiera co najmniej jeden zasób oceniony jako unikatowy, specyficzny lub inny rzadki. Zasoby unikatowe są w 6 gminach stanowiących 29\% badanych gmin. Zasobem występującym w największej liczbie gmin - 13 (stanowiących 62\% badanych gmin) jest atrakcyjność krajobrazowa i przyrodnicza dla turystyki. Razem z innymi zasobami przyrodniczymi dla turystyki, w tym ich indywidualnymi zestawami wymienionymi w tabeli 2, jest to 16 gmin (76\%). Rozwojowi turystyki mogą też służyć m.in. walory kulturowe w 12 gminach (57\%) i koleje wąskotorowe w 4, co daje razem 17 gmin z zasobami dla turystyki (81\%). W 6 gminach atutem jest położenie przy granicy lądowej, w 6 - zasób przyrodniczy stanowią surowce, w 4 - lasy ze względów produkcyjnych, w 5 - zasoby instytucjonalne, w 10 -gospodarcze (w 4 - kopalnie, w 7 -inne). 
Tabela 2. Klasyfikacja niepowtarzających się mocnych stron o charakterze zasobów

\begin{tabular}{|c|c|c|c|}
\hline Typ & Rodzaj & Opis mocnej strony - zasobu & Gminy ${ }^{\mathrm{a}}$ \\
\hline U1 & $\mathrm{k}$ & $\begin{array}{l}\text { Rozpoznawalne zasoby dziedzictwa kultury materialnej i niematerialnej o znaczeniu } \\
\text { ponadregionalnym (Pole Grunwaldzkie) }\end{array}$ & G \\
\hline U1 & $\mathrm{pr}$ & Unikalna roślinność pontyjska & Mk \\
\hline U1 & $\mathrm{pr}+\mathrm{k}$ & „Dzikość" Bieszczadów - mit i historia & $\mathrm{L}$ \\
\hline $\mathrm{U} 1+\mathrm{P}$ & $\mathrm{pr}$ & $\begin{array}{l}\text { Bogactwo przyrodnicze: Puszcza Białowieska, nieskażone środowisko, zbiornik wodny } \\
\text { Siemianówka, sieć rzeczna }\end{array}$ & $\mathrm{N}$ \\
\hline U2 & g & Stadnina koni huculskich w Gładyszowie i jej oddziaływanie na atrakcyjność gminy & U \\
\hline U2 & g & Atrakcyjność krajoznawcza, w tym największa odkrywka & $\mathrm{KI}$ \\
\hline S & $\mathrm{pr}$ & $\begin{array}{l}\text { Walory środowiska przyrodniczego: krajobraz pasm górskich, zbiornik wodny Klim- } \\
\text { kówka, duże powierzchnie zalesione, malownicze doliny łąk i pastwisk, rzeki i potoki }\end{array}$ & $U$ \\
\hline S & i & LGD „Dolina Rzeki Grabi” (współpraca z innymi gminami) & $\mathrm{Bu}$ \\
\hline R1 & i & Funkcjonująca fundacja Bieszczadzkiej Kolejki Leśnej & $\mathrm{C}$ \\
\hline $\mathrm{R} 2$ & i & Współpraca transgraniczna i dobre relacje z ukraińskimi partnerami & $\mathrm{H}$ \\
\hline R3 & i & Powołanie klastra „Budownictwo Polski Centralnej” & $\mathrm{KI}$ \\
\hline $\mathrm{R}+\mathrm{S}$ & pr & Walory przyrodniczo-krajobrazowe (morze, jeziora, rzeki, lasy, góra Rowokół) & Sm \\
\hline R1 & ps & Występowanie kopalin (kreda) & Mk \\
\hline R1 & $\mathrm{pr}$ & Wybrzeże klifowe & $\operatorname{Re}$ \\
\hline R1 & z & Infrastruktura kolejowa łącząca gminę z Ukrainą/Białorusią & $\mathrm{H}, \mathrm{N}$ \\
\hline $\mathrm{R} 2$ & $\mathrm{pr}$ & Wody geotermalne & $\operatorname{Re}$ \\
\hline $\mathrm{R} 2$ & $x$ & Bogate dziedzictwo i tradycje lecznictwa zdrojowego & $\mathrm{H}$ \\
\hline R3 & g & Marka regionalna - truskawka & $\mathrm{Bu}$ \\
\hline R3 & g & Rozwój rolnictwa ekologicznego & $\mathrm{Sm}$ \\
\hline R3 & $\mathrm{pr}$ & $\begin{array}{l}\text { Wysoka atrakcyjność turystyczno-rekreacyjna Boszkowa (ciąg jezior połączonych } \\
\text { kanałami) }\end{array}$ & W \\
\hline$P$ & g & Rosnąca liczba podmiotów gospodarczych wyższa niż średnia w województwie i kraju & W \\
\hline$P$ & g & Zróżnicowanie struktury podmiotów gospodarczych & W \\
\hline$P$ & g & Duża ilość upraw pieczarek i warzyw pod szkłem & W \\
\hline P & g & Istnienie wielu prężnych zakładów produkcyjnych i usługowych & $\mathrm{KI}$ \\
\hline P & g & Rozwinięte przetwórstwo wyrobów z drewna & So \\
\hline$P$ & g & Rozwinięte rolnictwo & Ps \\
\hline$P$ & i & $\begin{array}{l}\text { Zespół Szkół Rolniczych w Hańczowej kształcący znaczną część młodzieży i przygoto- } \\
\text { wujący do prowadzenia gospodarstw rodzinnych, agroturyzmu, obsługi turystyki }\end{array}$ & $U$ \\
\hline$P$ & $p+s$ & $\begin{array}{l}\text { Bardzo korzystne warunki dla tworzenia gospodarstw agroturystycznych. } \\
\text { Akceptacja tej formy działalności gospodarczej przez znaczną część mieszkańców. }\end{array}$ & Pw \\
\hline$P$ & $\mathrm{pl}+\mathrm{g}$ & $\begin{array}{l}\text { Zasoby lasów oraz przetwórstwo drewna, które rozwija się na bazie tych zasobów } \\
\text { wraz z tradycją rzemiosła drzewnego }\end{array}$ & $U$ \\
\hline P & $\mathrm{pl}+\mathrm{ps}$ & Zasoby wody, drewna, gazu, ropy, piaskowca & $\mathrm{L}$ \\
\hline$P$ & $\mathrm{pr}$ & Bardzo dobre warunki dla rozwoju turystyki łowieckiej i wędkarskiej & C \\
\hline $\mathrm{P}$ & $\mathrm{pr}$ & Długo zalegająca pokrywa śnieżna & $\mathrm{C}$ \\
\hline
\end{tabular}

U1, U2 - unikatowe (rozróżnienie opisane w tekście), S - specyficzne, R1, R2, R3 - rzadkie o zróżnicowanym poziome rzadkości (rozróżnienie opisane w tekście), P - powszechne, g - gospodarcze, i - instytucjonalne, k - kulturowe, p- przyrodnicze: pa - agroekologiczne, pl - leśne, pr - rekreacyjno-balneologiczne, ps - surowcowe, $x$ - inne, $z$ - techniczne i z zakresu zagospodarowania przestrzennego.

a Symbole jak w tabeli 1.

Źródła: dokumenty strategiczne według spisu literatury. 
Tabela 3. Klasyfikacja mocnych stron o charakterze zasobów występujących w więcej niż jednej gminie

\begin{tabular}{|c|c|c|c|}
\hline Typ & Rodzaj & Opis czynnika & Gminy \\
\hline S & k & Różnorodność kulturowa & $\mathrm{N}, \mathrm{H}$ \\
\hline S & k & $\begin{array}{l}\text { Tradycje/bogactwo kulturowe: zespoły ludowe i folklor, rękodzieło, } \\
\text { imprezy, zabytki architektury; tradycje regionalne }\end{array}$ & $\begin{array}{l}\text { C, J, Mk, N, Ps, Re, } \\
\text { Sm, So, Sz, U }\end{array}$ \\
\hline S & $\mathrm{pr}$ & Obszary objęte ochroną przyrody & $\mathrm{C}, \mathrm{H}, \mathrm{Sm}$ \\
\hline S & pu & Unikalne walory klimatyczne, zasoby wód leczniczych i borowiny & $\mathrm{H}$ \\
\hline$S+P$ & $\mathrm{pr}$ & $\begin{array}{l}\text { Atrakcyjność krajobrazowa i przyrodnicza/piękna przyroda/ } \\
\text { bogactwo flory i fauny/wysokie walory przyrodniczo-krajobrazowe }\end{array}$ & $\begin{array}{l}\text { C, H, L, Mk, Ps, Pw, } \\
\text { Re, Rz, So, Su, Sz, W }\end{array}$ \\
\hline R1 & ps & Złoża węgla brunatnego & $\mathrm{Br}, \mathrm{KI}, \mathrm{Su}, \mathrm{Sz}{ }^{\mathrm{b}}$ \\
\hline R1 & g & Kopalnia węgla brunatnego & $\mathrm{Br}, \mathrm{KI}, \mathrm{Su}^{\mathrm{c}} \mathrm{Sz}$ \\
\hline R2 & $\mathrm{pr}$ & $\begin{array}{l}\text { Bezpośredni dostęp do morza, piaszczyste plaże (szerokie, nieprzelud- } \\
\text { nione), korzystny morski mikroklimat, dobry stan kąpielisk }\end{array}$ & Mo, Ps, Re, Sm \\
\hline R2 & z & Atrakcyjna linia kolei wąskotorowej & C, H, Pw, Re \\
\hline R2 & $x$ & Położenie przygraniczne (lądowe) & $N, U, H, C$, So, $L$ \\
\hline $\mathrm{P}$ & $\mathrm{pr}+\mathrm{pa}$ & Dobre warunki dla rozwoju agroturystyki i upraw ekologicznych & $\mathrm{H}, \mathrm{Su}$ \\
\hline R3 & $\mathrm{pr}+\mathrm{pl}$ & Wysoki stopień lesistości gminy & $\operatorname{Re}, \mathrm{L}, \mathrm{C}$ \\
\hline P & z & Rozbudowana baza noclegowa & $N, \operatorname{Re}, L, P s$ \\
\hline $\mathrm{P}$ & z & Dobra infrastruktura sportowo-rekreacyjna i turystyczna & $\mathrm{N}, \mathrm{Re}, \mathrm{So}, \mathrm{Ps}$ \\
\hline $\mathrm{P}$ & g & $\begin{array}{l}\text { Rozwój agroturystyki i turystyki/gospodarstwa agroturystyczne/ } \\
\text { turystyka i agroturystyka }\end{array}$ & $\mathrm{Sm}, \mathrm{N}, \mathrm{Ps}$ \\
\hline
\end{tabular}

Symbole jak w tabeli 2.

a W gminach Postomino, Powidz i Rzeczenica również jeziora, w gminie Rzeczenica ponadto rezerwaty, pomniki przyrody i walory kulturowe (zabytki), w gminie Powidz - „wiele unikalnych okazów flory i fauny” (Strategia...

2002, s. 57), w gminie Horyniec - liczne osobliwości przyrody (Strategia promocji... 2015).

${ }^{\mathrm{b}}$ Z wyjątkiem gminy Brudzew uzupełnienie autora. Gminy wskazały tylko kopalnie.

c Uzupełnienie autora, gmina nie wskazała.

Źródła: dokumenty strategiczne według spisu literatury.

\section{Wykorzystanie zasobów w realnym rozwoju i w strategiach}

Do przejawów i mierników rozwoju należą dochody własne budżetów gmin per capita i wskaźnik przedsiębiorczości. Wysokie ich wartości w gminach nadmorskich Rewal i Mielno oraz górskich: Solina, Cisna i Lutowiska wynikają z wykorzystania zasobów (głównie przyrodniczych) dla rozwoju turystyki. W gminie Postomino duży udział w dochodach mają elektrownie wiatrowe, w czterech gminach - kopalnie odkrywkowe węgla brunatnego, a więc również zasoby przyrodnicze. W kilku gminach o wysokich wartościach wskaźnika dochodów własnych per capita decydowały nie zasoby będące czynnikami rozwoju, lecz (przy niewielkiej liczbie ludności gmin): podatek od lotnisk wojskowych w gminach Powidz i Buczek, domków letniskowych w gminie Powidz i przepompowni ropy w gminie Mielnik oraz działalność straży gminnej w gminie Rzeczenica (informacje z urzędów gmin). W gminach bieszczadzkich na wskaźnik dochodów własnych wpłynął znacząco podatek od mienia komunalnego, głównie dróg - wobec dużej powierzchni gmin (a więc i długości dróg) i małego zaludnienia. Na wysoki wskaźnik przedsiębiorczości w gminie Włoszakowice wpływała spora liczba przedsiębiorców budowlanych, pracujących na rynku ponad- 
lokalnym, także za granicą. Stanowią oni niewątpliwie zasób ludzki gminy, jeszcze w pełni nierozpoznany w strategii uchwalonej w 2004 r.

Planowane w strategiach wykorzystanie zasobów powinno być zawarte w wizjach i misjach, które są w większości badanych dokumentów (w niektórych tylko jedna z nich). Misja powinna spełniać większość cech, jakich Ackof (1993) wymaga od deklaracji programowej firmy, czyli m.in: uwypuklać specyfikę i wyróżniające w otoczeniu zdolności. Do cech misji zalicza się też unikalność i emocjonalność (Strategia rozwoju gminy i miasta Alwernia 2005).

Większość wizji i misji w badanych dokumentach określa zasoby i kierunki rozwoju, ale ogólnie, nie podkreślając ich specyfiki, np.: „Gmina Włoszakowice dąży do zrównoważonego rozwoju, wspierając przedsiębiorczość, wykorzystując potencjał turystyczny i walory przyrody oraz kultywując tradycje kultury i folkloru” (Uchwała... 2004, s. 18). Akcentowanie specyfiki najbardziej widoczne jest w misji gminy Solina: „Jesteśmy centrum turystyczno-uzdrowiskowym Bieszczadów położonym w najpiękniejszym zakątku Polski - w otoczeniu wód Zalewów Solińskiego i Myczkowieckiego, oferującym wszystkim: zdrowy i aktywny wypoczynek nad wodą i w górach, usługi leczniczo-sanatoryjne z wykorzystaniem miejscowych wód mineralnych, rozwiniętą infrastrukturę turystyczno-rekreacyjną, wypoczynek w gospodarstwach agroturystycznych i pensjonatach oraz możliwość inwestowania [...]" (Uchwała... 2015, s. 171). Odniesienie do specyfiki jest też w wizji gminy Narewka oraz misjach gmin Cisna i Lutowiska. Wobec powyższego wykorzystanie zasobów w strategiach odczytywano głównie ze struktury celów i działań.

Większość strategii nawiązuje do rozpoznanych zasobów. Przeważnie są to zasoby dla rozwoju turystyki. I tak, rozwój aktywności turystycznej i agroturystycznej wymieniany jest, „ze względu na bardzo wysokie walory przyrodniczo-krajobrazowe” wśród kierunków rozwoju społeczno-gospodarczego gminy Rewal (Aktualizacja strategii... 2012, s. 113). Większość kierunków działania dotyczy tu zagospodarowania turystycznego i rozwoju turystyki, w tym wzbogacania produktu turystycznego. Proponuje się m.in. doradztwo dla MSP w sektorze turystyki i promocję niepowtarzalnych walorów turystycznych w środowiskach inwestujących w usługi typu SPA \& Welness. „Stworzenie nowoczesnej (innowacyjnej) gospodarki opartej na atrakcyjnej, konkurencyjnej i całorocznej ofercie turystycznej" w oparciu o istniejące zasoby jest też jednym z trzech celów strategicznych w gminie Mielno. Zakłada się tam wykreowanie unikatowych w skali regionu produktów turystycznych - osobnych w każdej miejscowości (Strategia Rozwoju Gminy Mielno... 2014, s. 73).

W gminie Postomino na 14 celów pięć dotyczy zasobów kulturowych i rozwoju turystyki, m.in. „wykorzystania rzeki Wieprzy, jezior i pasa nadmorskiego do celów rekreacyjno-wypoczynkowych [...] lepszego wykorzystania walorów przyrodniczo-krajobrazowych dla rozwoju różnych form turystyki [...] rewitalizacji dóbr kultury oraz dziedzictwa kulturowego [...] wykorzystania położenie gminy dla pozyskania inwestorów [w tym inwestorów z branży turystycznej - JS] i unowocześnienia gospodarki, stworzenia spójnego programu promocji i rozwoju turystycznego, rolniczego i gospodarczego gminy" (Strategia Rozwoju Społeczno-Gospodarczego Gminy Postomino... 2007, s. 80-82).

W gminie Smołdzino jednym z trzech celów strategicznych jest „konkurencyjna gospodarka i turystyka”, a wśród 18 celów tzw. operacyjnych²: „promocja gminy jako atrakcyjnego obszaru turystycznego, turystyczne wykorzystanie walorów środowiska naturalnego i kulturowego ze szczególnym uwzględnieniem potencjału turystyki wodnej, rowerowej

\footnotetext{
${ }^{2}$ Cele zwane operacyjnymi przeważnie nimi nie są, powinny nazywać się szczegółowymi. Cele operacyjne to cele planów operacyjnych. Powinny mieć właściwą tym planom konkretność, w tym mierzalność.
} 
i pieszej, wspieranie rozwoju rekreacji i turystyki jako czynników dynamizujących lokalny rozwój gospodarczy oraz rozbudowa infrastruktury turystycznej na terenie gminy" (Rorzkowski, s. 70).

W gminie Uście Gorlickie turystyczno-uzdrowiskowy kierunek z naciskiem na kilka form rekreacji i turystyki na bazie potencjału naturalnego uznano za stwarzający największe szanse (Guzdek i Sady 1998). W gminie Jabłonka „zrównoważony rozwój turystyki” jest jednym z czterech celów strategicznych, a wśród celów operacyjnych jest m.in. „Promocja turystyczna gminy [...]. Zachowanie, ochrona, promowanie i rozwój dziedzictwa naturalnego i kulturowego [...]. Rozwój instytucji kultury oraz udostępnianie dziedzictwa kulturowego". Dla celu strategicznego „aktywność mieszkańców i lokalny rynek pracy” jako jeden z kierunków działania wskazano rozwój agroturystyki (Strategia rozwoju gminy Jabłonka... s. 59, 64).

Skutkiem rozbudowanej struktury strategii gmin bieszczadzkich (zwłaszcza Cisna i Lutowiska) jest wielość celów dotyczących zaspokajania potrzeb społecznych. Mniej celów dotyczy gospodarki. W gminie Lutowiska są to m.in. trzy cele dotyczące lasów i gospodarki leśnej: „Rozwinięte funkcje pozaprodukcyjne lasów [...]. Dostępne nowe miejsca pracy związane z gospodarką leśną [...]. Powszechna ochrona lasów, trwałość utrzymania i ciągłości ich użytkowania". Tylko jeden cel dotyczy turystyki (nic niemówiący o rozwoju): „Wysoka atrakcyjność turystyczna gminy” (Plan Strategiczny... 1997, s. 48, 49). W gminie Cisna kilka celów dotyczy gospodarki i zarazem wykorzystania zasobów, m.in: „Różnorodna i unikalna całoroczna oferta turystyczna na wysokim poziomie [...]. Utworzenie bogatej infrastruktury towarzyszącej rozwojowi bazy turystycznej [...]. Rozwinięte gospodarstwa agroturystyczne prowadzące produkcję »zdrowej żywności« [...]. Zwiększenie zakresu i stopnia przetworzenia drewna [...]. Bogata oferta lokalnego rzemiosła artystycznego i rękodzielnictwa" (Strategia Rozwoju Gminy Cisna... s. 34, 37, 38).

W bardziej prawidłowej strukturze 8 celów w gminie Solina połowa z nich dotyczy poprawy i utrzymania stanu oraz lepszego wykorzystania zasobów (dziedzictwa kulturowego, środowiska naturalnego, ładu przestrzennego). Dla celu strategicznego „Wyższy poziom wykorzystania potencjału gospodarczego gminy" jako cele operacyjne sformułowano m.in.: „Gmina Solina jako centrum turystyczne dla Bieszczadów i okolic [...]. Wykorzystane turystycznie zasoby wód mineralnych [...]. Rozwinięta nowoczesna oferta uzdrowiskowa [...]. Wykreowana marka gminy [...]. Poprawa poziomu rozwoju lokalnego rzemiosła i rękodzielnictwa" (Uchwała... 2015, s. 174).

Wykorzystanie rzadkich zasobów przewidziano w gminie Horyniec, wymieniając wśród strategicznych obszarów rozwoju gminy turystykę uzdrowiskową, aktywną i kulturową oraz budowę marki gminy uzdrowiskowej (Strategia promocji i rozwoju... 2015).

W gminie Mielnik wśród czterech celów rozwoju są: „kontynuowanie tradycyjnej gospodarki rolnej opartej na zasobach naturalnych i doświadczeniu gospodarzy [...] oraz racjonalne wykorzystanie zasobów naturalnych gminy i jej walorów krajobrazowych i kulturowych w turystyce i działalności gospodarczej” (Cieślukowski i in. 2001, s. 102-103). Wśród zadań realizacyjnych są m.in. współdziałanie z sąsiednimi gminami w organizacji spływów Bugiem, utworzenie tzw. „zabezpieczonej ruiny” na Górze Zamkowej, budowa kompleksu sanatoryjno-wypoczynkowego wykorzystującego wody solankowe (Cieślukowski i in. 2001).

W gminie Narewka jednym z czterech obszarów priorytetowych jest rozwój funkcji turystycznych na bazie walorów przyrodniczych, krajobrazowych, historycznych oraz dziedzictwa kulturowego, a wśród celów są: rozwój turystyki, agroturystyki i rekreacji oraz zachowanie i odbudowa dziedzictwa kulturowego (Szot-Gabryś 2015). 
W strategii dla gminy Grunwald nawiązania do zasobów są bardzo ogólne, bez ich nazwania. Przewidziano działania promocyjne nastawione na prezentację atutów gminy i lokalnych zasobów. Wśród kierunków działań jest „budowanie przewagi konkurencyjnej MŚP w oparciu o odtwarzanie gospodarczego dziedzictwa regionu i zasobów lokalnych", jest też mowa ogólnie o oznakowaniu i inwentaryzacji obiektów cennych kulturowo i historycznie, zachowaniu i zabezpieczeniu dziedzictwa kulturowego i ochronie obiektów zabytkowych (Strategia Rozwoju Społeczno-Gospodarczego... 2016, s. 79).

Wypromowanie wizerunku gminy Rzeczenica i jej oferty turystycznej w oparciu o walory historyczne, geograficzne i przyrodnicze to jeden z 10 celów głównych w strategii tej gminy (Strategia Rozwoju Gminy..., 2007). Również w gminie Powidz turystykę uznano za jedną z najważniejszych dziedzin gospodarki gminy (Strategia zrównoważonego rozwoju... 2002).

Wykorzystanie specyficznych, choć nie wybitnych zasobów założono w gminie Włoszakowice, wskazując na potrzebę stymulowania rozwoju przedsiębiorczości wykorzystującej aktywność mieszkańców i lokalny potencjał. Za sektor wiodący gminnej gospodarki uznano turystykę, zakładając modernizację i rozbudowę bazy turystycznej oraz wykorzystanie bogatego dziedzictwa kulturowego, w tym tradycji folklorystycznych (Uchwała... 2004).

Wielofunkcyjny rozwój wykorzystujący rozpoznane zasoby zakłada gmina Buczek. Cele sformułowane są niepoprawnie metodycznie (nie określają stanów do osiągnięcia lub utrzymania), ale wskazują dziedziny rozwoju, którymi mają być: 1) rolnictwo i nowoczesna produkcja rolna (bazujące na dobrych glebach i warunkach klimatycznych oraz rozwiniętym warzywnictwie i sadownictwie), 2) przedsiębiorczość i inwestycje. Zakłada się dalszą promocję marki regionalnej (buczkowska truskawka) i promocję obszaru jako zagłębia producentów zdrowej żywności, w tym przyciąganie inwestorów z branży przetwórstwa owocowo-warzywnego. Rekomendowane są działania na rzecz rozwoju agroturystyki z uwagi na atrakcyjne położenie (dolina rzeki Grabi, duża ilość lasów, szlaki turystyczne). Wątpliwość budzi proponowana aktywizacja bezrobotnych oparta na samozatrudnieniu (Strategia rozwoju gminy Buczek... 2015).

Specyficzne są strategie gmin z zasobami i wydobyciem węgla brunatnego. W gminie Kleszczów przewidziano nowe specjalizacje po zakończeniu wydobycia, zapisując jako cel „rozwój gospodarczy w oparciu o innowacyjne projekty” (Długookresowa strategia... 2015, s. 95). W gminie Szczerców jeden z trzech celów strategicznych sformułowano jako „nie tylko węgiel brunatny” - dywersyfikacja lokalnej gospodarki (Achremowicz i Boryczka 2016). W gminie Brudzew na liście 14 celów tworzących wybrany wariant rozwoju do górniczej specyfiki gminy nawiązuje cel „Stworzyć warunki dla wykorzystania terenów pokopalnianych dla turystyki" (Strategia rozwoju społeczno-gospodarczego... 2003, s. 85). Interesujące jest, że nie znalazły się na tej liście następujące z 44 wstępnie sformułowanych celów: „Umożliwić eksploatację zasobów naturalnych” (cel wstępnie uznany za niezbędny, z kierunkiem działania „Utworzenie odkrywki Dobrów”), „Wykorzystać położenie gminy nad rzeką Wartą [...]. Stworzyć warunki dla rozwoju gminy w oparciu o zasoby naturalne [...] Przeciwdziałać likwidacji kopalń i elektrowni" (Strategia rozwoju społeczno-gospodarczego... 2003, s. 79-81). W Planie Rozwoju Lokalnego (2009) gminy Sulmierzyce w części dotyczącej celów i sposobów ich osiągania brak jest jakiejkolwiek wzmianki o węglu brunatnym, brak też jest celów dotyczących gospodarki i rynku pracy, co wynika zapewne z charakteru dokumentu, niebędącego strategią. 


\section{Podsumowanie i wnioski}

W badanych dokumentach strategicznych rozpoznano jako zasoby 33 niepowtarzające się mocne strony i 15 powtarzających się w więcej niż jednej gminie. Wszystkie zostały sklasyfikowane jako: unikatowe, specyficzne, rzadkie niewykazujące istotnej specyfiki albo powszechne. Każda badana gmina zawiera co najmniej jeden zasób oceniony jako unikatowy, specyficzny lub inny rzadki. Zasoby unikatowe są w 6 gminach stanowiących $29 \%$ badanego zbioru. Rozpoznano 5 rodzajów zasobów specyficznych, niektóre z nich występują w wielu gminach, w każdej o odmiennych, niepowtarzalnych cechach. Zasobów rzadkich jest 12 niepowtarzających się i 6 powtarzających się w różnych gminach.

W ujęciu rodzajowym sklasyfikowano 21 zasobów przyrodniczych, 12 gospodarczych, 5 instytucjonalnych, 4 techniczne i z zakresu zagospodarowania przestrzennego, 3 kulturowe i 2 innego rodzaju. W największej liczbie gmin, stanowiącej $81 \%$ badanego zbioru, występują zasoby dla turystyki, w 76\% są to zasoby przyrodnicze, w 57\% - kulturowe.

Największą rolę w dotychczasowym rozwoju w badanych gminach (przejawiającą się wysokimi dochodami własnymi budżetu gmin) odgrywały takie zasoby rzadkie, choć nie specyficzne, jak: surowce mineralne (węgiel brunatny) oraz walory turystyczne strefy brzegowej morza. Decydowały o tym: popyt na rekreację nadmorską, odkrywkowa technologia wydobycia węgla brunatnego i rozwiązania podatkowe. Wyraźną, ale mniejszą rolę odgrywały w rozwoju walory turystyczne gór, mimo większej specyfiki. Mało widoczne jest przełożenie na wskaźniki rozwoju innych zasobów specyficznych, unikatowych.

Rola badanych zasobów w całokształcie strategii zależy od roli domen (dziedzin, segmentów), którym one służą w całości gospodarki gminy oraz od roli problematyki rozwoju gospodarczego w całokształcie rozwoju planowanego w strategii. Podstawą rozwoju planowanego w strategiach jest wiele rozpoznanych zasobów, ale nie wszystkie. W największej liczbie gmin - aż w 16 - planuje się wykorzystać zasoby przyrodnicze i kulturowe dla rozwoju turystyki, nie tylko w gminach, gdzie są one wybitne, a segment ten jest dobrze rozwinięty. Cele związane z turystyką stanowią 10-33\% liczby celów strategicznych, a w Rewalu nawet ich większość. W nielicznych gminach planuje się wykorzystanie innych zasobów: uzdrowiskowych, leśnych, agroekologicznych, doświadczeń gospodarzy, marki regionalnej, rozwiniętej przedsiębiorczości. Żadna strategia w sposób wyraźny nie nawiązuje do położenia przygranicznego. Specyficzny charakter mają strategie gmin górniczych, które planują dywersyfikację gospodarki ze względu na wyczerpywanie się surowca. Oprócz gospodarki strategie obejmują i inne dziedziny, np. sferę spoczną, infrastrukturalną i inne. W większości strategii te inne dziedziny przeważają.

W wielu strategiach nie podkreśla się specyfiki zasobów i ich kombinacji ani specyfiki specjalności gospodarczych gmin czy ofert. Szczególnie widoczne jest to w misjach. Dobrych misji - akcentujących specyfikę gminy, unikalnych i pasjonujących - jest niewiele.

Zasygnalizowany wcześniej niedostatek relatywizacji czynników skłania do poszukiwania lepszych od dotychczas stosowanych rozwiązań metodycznych. W. Potwora (1998) widzi możliwość zwiększenia obiektywizacji w dużej liczbie uczestników prac, ich kompetencjach oraz porównaniach regionalnych, krajowych i międzynarodowych. M. Dutkowski (2003) proponuje przeprowadzanie analizy SWOT przez ekspertów.

W badaniach skoncentrowano się na ocenie roli pojedynczych zasobów służących rozwojowi społeczno-gospodarczemu gmin. Za specyficzne zasoby są też w literaturze uważane kombinacje zasobów (np. Pietrzyk 2001). Ich diagnozowanie i tworzenie nowych 
mogą ułatwić macierze SWOT lub schematy blokowe. Ich sporządzanie rekomenduje się jako wniosek do praktyki planowania strategicznego.

Jako wniosek do metodyki planowania strategicznego proponuje się wzbogacenie analizy relacji miedzy czynnikami rozwojowymi o relacje między atutami a słabościami, a także między samymi atutami.

\section{Literatura}

Achremowicz T., Boryczka R., 2016, Strategia Rozwoju Gminy Szczerców na lata 2016-2025 wraz z planem rozwoju lokalnego na lata 2016-22, załącznik do Uchwały Nr XVIII/184/16 Rady Gminy Szczerców z dnia 21.04.2016 r., Szczerców.

Aktualizacja strategii rozwoju gminy Rewal do roku 2020, 2012, Business Mobility International Spółka z o.o, Rewal.

Bank Danych Lokalnych GUS, dostępne na: www.stat.gov.pl.

Brooks M. P., 2002, Planning Theory for Practitioners, Planners Press, American Planning Association, Chicago.

Chądzyński J., Nowakowska A., Przygodzki Z., 2007, Region i jego rozwój w warunkach globalizacji. CeDeWu. PL Wydawnictwa Fachowe.

Cieślukowski C., Sawicka W., Dudzińska M., Szypiłło M., Strategia rozwoju Gminy Mielnik na lata 2001-2010, (nie podano roku i miejsca), dostępne na: http://bip.ug.mielnik.wrotapodlasia. pl/4899db4e9a3/str_rozwoju.htm.

Długookresowa Strategia Rozwoju Gminy Kleszczów 2030+. Projekt, 2015, Lider Projekt Sp. z o.o. Kleszczów - Poznań.

Dutkowski M., 2003, Analiza SWOT w badaniach lokalnych i regionalnych - problemy stosowania i główne błędy interpretacji, [w:] H. Rogacki (red.) Problemy interpretacji wyników metod badawczych stosowanych w geografii społeczno-ekonomicznej i gospodarce przestrzennej, Bogucki Wydawnictwo Naukowe, Poznań, s. 43-49.

Grosse T.G., 2007, Wybrane koncepcje teoretyczne i doświadczenia praktyczne dotyczqce rozwoju regionów peryferyjnych, Studia Regionalne i Lokalne, 8 (27), s. $27-49$.

Guzdek T., Sady T., 1998, Strategia rozwoju gminy Uście Gorlickie, Urząd gminy Uście Gorlickie, Regionalny Ośrodek Usług Spółdzielczych w Krakowie, Kraków.

Hausner J., 2008, Ekonomia społeczna i rozwój, Ekonomia społeczna teksty, 12, dostępne na: www. ekonomiaspoleczna.pl.

Inny słownik języka polskiego, 2000, PWN, Warszawa.

Pierścionek Z., 2003, Strategie konkurencji i rozwoju przedsiębiorstwa, Wydawnictwo Naukowe PWN, Warszawa.

Pietrzyk I., 2001, Zasoby specyficzne jako determinanta konkurencyjności regionów, [w:] A. Klasik (red.) Konkurencyjność miast i regionów a przedsiębiorczość i przemiany strukturalne, Seria Prace Naukowe Akademii Ekonomicznej im. Karola Adamieckiego w Katowicach, Katowice, s. 11-24.

Plan rozwoju lokalnego gminy Sulmierzyce na lata 2009-2015, 2009, ELPA Spółka z o. o. Sulmierzyce.

Plan Strategiczny Gminy Lutowiska do roku 2010, 1997, dostępne na: http://bip.lutowiska.pl/drukuj. php? id=15\&a=150.

Potwora W., 1998, Wymiary analizy strategicznej a formułowanie strategii w marketingu regionalnym, [w:] S. Dolata (red.), Funkcjonowanie samorzqdu terytorialnego-doświadczenia i perspektywy, t. II, Uniwersytet Śląski, Opole, s. 441-449 
Przewoźniak M., 1991, Krajobrazowy system interakcyjny strefy nadmorskiej w Polsce, Wydawnictwo Uniwersytetu Gdańskiego, Gdańsk.

Ray C., 2001, Culture economies, Centre for Rural Economy, Newcastle.

Rorzkowski A., Strategia Rozwoju Gminy Smołdzino na lata 2016-2026 (nie podano roku i miejsca).

Sołtys J., 2008, Metody planowania strategicznego gmin z uwzględnieniem aspektów przestrzennych i rozwoju zrównoważonego, seria Monografie, 87, Wydawnictwo Politechniki Gdańskiej, Gdańsk.

Sołtys J., 2014, Czynniki rozwojowe w dokumentach strategicznych miast powiatowych na obszarze peryferyjnym województwa pomorskiego, Prace Naukowe Uniwersytetu Ekonomicznego we Wrocławiu 333, s. 11-21.

Strategia promocji i rozwoju gminy Horyniec-Zdrój na lata 2015-2020, 2015, Instytut Dobrych Ekorozwiązań „Alternatywa” Sp. z o.o. Rzeszów.

Strategia rozwoju gminy Buczek na lata 2015-2020, 2015, Łódzka Agencja Rozwoju Regionalnego, Łódź.

Strategia Rozwoju Gminy Cisna na lata 2008-2010, 2008, dostępne na: http://www.cisna.itl.pl/bip/ atach/4/22/36/strategia.pdf.

Strategia rozwoju gminy i miasta Alwernia, 2005, Raport z sesji strategicznej. Fundacja Promocj i Gospodarczej Regionu Krakowskiego, grudzień 1998, aktualizowana grudzień 2005 rok http:// www.alwernia.pl/UserFiles/File/ALWERNIA-strategia\%202005.pdf.

Strategia rozwoju gminy Jabłonka na lata 2015-2020 (bez daty i miejsca) dostępne na: http://jablonka.nazwa.pl/v2/downloads/inne/projekt_strategia_jablonka.pdf.

Strategia Rozwoju Gminy Mielno na lata 2014-2022, 2014, załącznik do Uchwały Nr LIX/589/2014 Rady Gminy Mielno z dnia 2 października 2014 r., Gmina Mielno, Mielno.

Strategia Rozwoju Gminy Rzeczenica 2007-2020, 2007, Rzeczenica.

Strategia rozwoju społeczno-gospodarczego gminy Brudzew 2003-2013, 2003, Raport, Brudzew.

Strategia Rozwoju Społeczno-Gospodarczego Gminy Grunwald na lata 2016-2026: Projekt do konsultacji, 2016, Gierzwałd.

Strategia Rozwoju Społeczno-Gospodarczego Gminy Postomino na lata 2007-2015, 2007, Business Mobility International Spółka z o.o., Postomino.

Strategia zrównoważonego rozwoju gminy Powidz, 2002, Uchwała Nr XXXIV/217/02 Rady Gminy Powidz z dnia 17 września 2002 roku w sprawie uchwalenia strategii rozwoju gminy Powidz.

Szot-Gabryś T., 2015, Program Rozwoju Gminy Narewka na lata 2015-2020, 2015, Fundacja Rozwoju Demokracji Lokalnej - Podlaskie Centrum, dostępne na: http://narewka.pl/narewkagmina/userfiles/file/gm/aktualpdf/pr_gn_projekt.pdf.

Uchwała nr XV/135/15 Rady Gminy Solina z dnia 30 października 2015 r. w sprawie przyjęcia Strategii Rozwoju Gminy Solina do roku 2025, 2015, Rada Gminy Solina.

Uchwała nr XXIV/197/2005 Rady Gminy Włoszakowice w sprawie przyjęcia Strategii Rozwoju Gminy Włoszakowice na lata 2004-2013, 2004, Urząd Gminy Włoszakowice.

Ustawa o zasadach prowadzenia polityki rozwoju z 6 grudnia 2006 r., Dz. U. nr 227 z 2006 poz. 1658 z późn. zm.

Zajda K., 2013, Innowacja w wiejskiej przedsiębiorczości: Studium przypadku działalności gospodarczej z obszaru Doliny Pilicy, Studia Regionalne i Lokalne, 1 (51), s. 91-106. 


\section{Summary}

The aim of the article was to identify the role of specific and rare (including unique) resources in the development strategies of rural communes (in Polish: gmina). Peripheral communes (that is, located outside the sub-regions of big cities) were examined. Communes were selected from the ones with: the highest own revenue of communal budget per capita averaged for the years 2010-14; the highest indicator of natural persons conducting economic activity per 1,000 people at working age and the occurrence of rare resources (spas, sightseeing attractions). Communes adjacent to towns were excluded from analysis. Lists of development factors for SWOT analysis and other elements of strategic plans provided sources of information. Research methodology involved analysis and classification of studied development factors and further analysis of other parts within documents. The research results indicate that mineral resources (lignite) and tourist values, especially those associated with the sea and beaches have contributed to development of rural communes to the highest extent. Strategic documents of communes vary in quality. In many cases the strategies fail to adequately expose the specificity of resources. Methodological errors in the SWOT analysis are common. Positive missions emphasizing the specificity of communes are rare. 